\title{
Policy coherence for national climate change adaptation and invasive species management in four countries
}

\section{Abstract}

This study explores the opportunities for interlinkages across national planning processes for invasive species management (ISM), national climate change adaptation plans (NAPs), national biodiversity management plans (NBSAPs), and other related policies. Focusing on four countries - Pakistan, Zambia, Kenya, and Ghana - the paper aims to identify policy recommendations for more integrated approaches and to achieve greater efficiency in resource allocation and spending. It finds that there is currently very little integration between these policy areas, and little overlap in implementation systems. It identifies sub-national planning and governance systems as an optimal area for increased harmonization of policy and practice to facilitate locally-led climate adaptation and area-specific responses to ISM issues. 


\section{Introduction}

This study explores the opportunities for interlinkages across national planning processes for invasive species management, climate change adaptation plans, national biodiversity management plans, and other related policies.

As international attention has focused on the challenges presented by climate change - both in terms of mitigating greenhouse gas (GHG) emissions and adapting to hazards caused or exacerbated by climate change - national and local governments have started to develop policies and strategies for climate change adaptation. Following the development of the Cancun Adaptation Framework (UNFCCC, 2010), national governments have started to develop national adaptation plans (NAPs), with several governments receiving funding to support this process through multilateral funding mechanisms such as the Green Climate Fund (GCF).

Comparatively little attention has been given to the issue of managing invasive species, despite the impacts of invasive species management (ISM) costing countries an estimated \$1.4 trillion per year (Pimentel, et al., 2001). With the landmark fifteenth Conference of Parties (COP15) to the Convention on Biodiversity (CBD) due to be held in 2021, and issues relating to biodiversity becoming increasingly important for national governments, ISM has become an important topic, particularly in relation to the agriculture sector, and national governments are starting to also develop new policies related to ISM. Moreover, the Sustainable Development Goals, agreed in 2015, include a target under Goal 15 for Parties to "introduce measures to prevent the introduction and significantly reduce the impact of invasive alien species on land and water ecosystems", by 2020 (UN, 2015).

Climate change is expected to drive changes in the distribution of invasive pests and weeds and may weaken plant and ecosystem resilience attack from associated pathogens (Heeb, Jenner, \& Cock, 2019) (Cavicchioli, Ripple, \& Webster, 2019) (Pyšek, et al., 2020) (FAO, 2020) (IPPC, 2021). Climate change is also altering ecosystems, changing pests' life cycles and creating new niches where pests and plant diseases can thrive (IPPC, 2019). Meanwhile, many of the ministries and agencies involved in the policy and planning processes for climate change adaptation are also involved or responsible for ISM.

As funding and focus on these two issues of growing importance increase, this study aims to provide a timely analysis of the current status of harmonisation of these two intrinsically interconnected policy areas, and to provide recommendations for policymakers to exploit opportunities for integrated approaches. To do this, the paper aims to answer the following key questions:

- What are the commonalities and differences in approaches in climate change adaptation and ISM policies?

\section{- To what degree do each of these policy areas consider both adaptation and ISM?}

- What are the opportunities for integrated approaches? What benefits would these bring?

This paper focuses on four country contexts: Pakistan, Zambia, Kenya, and Ghana. Each of these countries is considered to be highly vulnerable to climate change impacts, as well as facing challenges with invasive insect and plant species (USAID, n.d.). Each of these countries are also part of the Action on Invasives ${ }^{1}$ programme, led by CABI.

\section{Methodology}

The paper uses a document review method, focusing on the current national policies of the four focus countries, as made available online, in English, on official government websites. This semi-systematic approach was used to identify all policies deemed relevant to climate change adaptation and ISM in each country, whether those issues were specifically addressed or not. Other official documentation was

\footnotetext{
${ }^{1}$ See: https://www.invasive-species.org/actions/action-on-invasives/
} 
included where relevant, such as official government submissions to the CBD and United Nations Framework Convention on Climate Change (UNFCCC).

For the purposes of this paper, issues related to invasive species of fish and livestock (and associated problems such as disease) are not covered.

\section{Context}

This section sets out the context of national policy processes for climate change adaptation and invasive species management, respectively, particularly in the context of major international, multilateral agreements and conventions.

\section{Climate change adaptation}

The Intergovernmental Panel on Climate Change (IPCC) defines climate change adaptation as, "The process of adjustment to actual or expected climate and its effects" (IPCC, 2014). It includes how human intervention may facilitate adjustment to expected impacts in natural systems, including agriculture. Adaptation also includes societal and economic responses. In agricultural communities, this may involve farmers diversifying their income through non-agricultural activities, or shifting production to a new area.

There are generally considered to be two main types of adaptation, incremental and transformational. Incremental adaptation is defined by the IPCC (2014) as, "actions where the central aim is to maintain the essence and integrity of a system or process at a given scale". At a farm level, this may include, for example, agricultural practices to improve water retention during drought periods, or using seed varieties more resilient to drought conditions. Transformational adaptation is defined by the IPCC (2014) as, "[actions] that change the fundamental attributes of a system in response to climate and its effects." It is considered to go beyond household or farm-level actions, to include 'system-wide' changes in governance, markets, policy, power structures, and landscapes (Grist, 2014) (Bahadur, et al., 2015) (Lonsdale, Pringle, \& Turner, 2015).

\section{National Adaptation Plans}

At the $16^{\text {th }}$ UNFCCC Conference of the Parties (COP16) in 2010, parties agreed to the Cancun Adaptation Framework, which established a process for the least developed countries (LDCs) to be supported, through finance and technical assistance, to develop National Adaptation Plans (NAPs), and invited all other parties to also develop NAPs, to enhance action on climate adaptation globally. Compared to the precursor process of National Adaptation Plans of Action (NAPAs), which were focused primarily on short-term actions in high-priority sectors, NAPs were established to consider medium-long term adaptation plans which should be integrated with wider national planning processes to ensure climate-resilient development pathways (UNFCCC, 2011). Yet a decade on, only 22 developing countries $^{2}$ have formally submitted NAPs or sectoral adaptation plans (UNFCCC, n.d.). However, 52 countries have now had NAP 'readiness support' funding approved by the Green Climate Fund (GCF), including 16 LDCs (GCF, GCF Support for NAPs, 2020), so NAP planning activities are expected to increase in the coming months and years.

\footnotetext{
2 'Developing countries' in this context are defined as 'non-Annex 1 Parties' to the UNFCCC. Annex 1 parties are the 43 more economically developed countries. The full list of Annex 1 and non-Annex 1 countries is available here: https://unfccc.int/process/parties-non-party-stakeholders/parties-convention-and-observer-states
} 


\section{Invasive species}

The Convention on Biological Diversity (CBD) defines invasive species as "species whose introduction and/or spread outside their natural past or present distribution threatens biological diversity" (CBD, n.d.). Invasive species can include animals, plants, fungi and microorganisms. For the purposes of this study, fish and livestock invasive species will not be covered. Invasive insect pests and plants can wreak havoc on farming communities, damaging crops, using up precious water and mineral resources, and outcompeting native species. Ecosystems that have been invaded by non-native species may not have the natural predators and competitors present to control their populations. Native ecosystems that have undergone human-induced disturbance, such as from agriculture or logging, are often more prone to invasions (CBD, n.d.).

\section{Aichi Biodiversity Targets}

In 2010, Parties to the CBD set out 20 targets to improve the state of biodiversity by 2020 . They are known as the Aichi Biodiversity Targets. Target 9 focuses on ISM, with countries committing to the following: "By 2020, invasive alien species and pathways are identified and prioritized, priority species are controlled or eradicated, and measures are in place to manage pathways to prevent their introduction and establishment" (CBD, 2020). In addition, the links between climate change and biodiversity conservation are also recognised through Target 15, which commits Parties to ensure that, "By 2020, ecosystem resilience and the contribution of biodiversity to carbon stocks has been enhanced, through conservation and restoration, including restoration of at least 15 per cent of degraded ecosystems, thereby contributing to climate change mitigation and adaptation and to combating desertification" (ibid).

Signatories to the Aichi Biodiversity Targets were tasked with developing National Biodiversity Strategies and Action Plans (NBSAPs), aimed at achieving the twenty targets by 2020. In all, 162 countries developed such plans in accordance with the CBD's Strategic Plan for Biodiversity (CBD, 2020). However, by 2020, none of the twenty targets were achieved globally (CBD, 2020). In part, this was due to the Targets being considered to have been designed poorly in terms of measurability and being realistic (Green, et al., 2019). Preparations are currently underway to determine the post-2020 Global Biodiversity Framework (CBD, 2020), expected to be agreed at the CBD COP15 in China in 2021, after which national governments are likely to begin to prepare new NBSAPs, or similar national policies.

\section{International Plant Protection Convention}

The International Plant Protection Convention (IPPC) is an intergovernmental treaty established in 1997, that aims to protect the world's plant resources from the spread and introduction of pests, and promote safe trade of agricultural goods and forest products (IPPC, 1999). It also established the International Standards for Phytosanitary Measures (ISPMs), considered the global standard in plant protection approaches (IPPC, 2021). The IPPC provides capacity building support to Parties to the treaty to implement the ISPMs and the principles of the treaty.

The IPPC's 2020-2030 Strategic Framework recognises the interrelated physical risks posed by climate change and invasive species in agriculture and forestry (FAO, 2020). It notes that the IPPC has not given due consideration to the interrelated nature of climate change and plant health to date, but sets out a plan to address this over the coming ten years. This will include the following measures:

- A higher level of cooperation with relevant international organizations with regard to climate change and capacity building, to ensure that evaluations of climate change impacts incorporate pest related impacts;

- Ensuring pest management guidelines value and enhance ecosystem services and do not negatively impact GHG emissions mitigation actions or the resilience of the ecosystem to climate change hazards; 
- Engagement with international climate change bodies, such as the UNFCCC, IPCC, Green Climate Fund, and Global Environment Facility to share adaptation strategies for responding to the impacts of climate change and mainstream phytosanitary policies into climate change policies;

- And to establish a forum for the systematic analysis and discussion of climate change and plant health threats.

In 2021, the IPPC produced a guidance note on plant health and climate change, summarising the interlinkages between pest and disease risks, and physical climate change hazards (IPPC, 2021a). It highlights that climate change increases the risk of pests and diseases to find favourable climate conditions in areas previously uninhabitable to them and consequently spread to these areas. It also notes that pest and disease risks can undermine climate adaptation and mitigation efforts, particularly by causing tree mortality and land degradation.

\section{Findings}

This section sets out the findings from a review of the main policies, plans, strategies, and processes at a national level for climate change adaptation and ISM in Pakistan, Zambia, Ghana, and Kenya. It also provides a snapshot of the current policy development status in relation to these issues in each country, based on officially published and publicly available documentation, and the existing governance structures for these policy areas.

\section{Pakistan}

Pakistan is among the countries most vulnerable to climate change, facing a multitude of climate hazards ranging from extreme heat, dust storms, and acute water shortages, to glacial lake outburst floods and erratic rainfall patterns (Government of Pakistan, 2012). Pakistan is ranked as the $152^{\text {nd }}$ country in the Global Adaptation Index, with a high vulnerability to climate change impacts, and a low level of 'readiness' to cope with the expected impacts (ND-GAIN, 2021).

Agriculture and agro-forestry are major economic sectors. Agriculture contributes $19.5 \%$ of Pakistan's GDP, employs $42 \%$ of the labour force, constitutes $65 \%$ of export earnings, and provides livelihoods to $62 \%$ of the population (Government of Pakistan, 2018). The National Food Security Policy highlights that, "Pakistan needs to build strong resilient agriculture sector to cope with the climate change risks. Climate change projections indicate that there will be greater variability in the weather with more frequent extreme events such as floods and droughts. Much of the impact of these changes will be on the agriculture sector, which needs mechanisms to cope and adapt" (Government of Pakistan, 2018).

The Policy also notes that pests and diseases are one of several constraints to sector growth. Pakistan is reported to have nearly 500 invasive species, although to date only 5 plant species have been able to establish to a degree where serious damage has been caused. These are Prosopis Juliflora (a low height spiny shrub), Eichhornia crassipes (a common water hyacinth), Salvinia molesta (an aquatic weed), Parthenium hystrophorus (a rangeland weed), Lantana camara (an ornamental flowering shrub), and the most invasive plant in Pakistan, Broussonetia papyrifera (paper mulberry) (Asif, 2018). However, there has never been a comprehensive national assessment of biodiversity status and trends in Pakistan (Government of Pakistan, 2014).

The national policies, plans, and strategies for Pakistan reviewed for this study are detailed in Table 1: 


\begin{tabular}{|c|c|c|c|}
\hline Document & $\begin{array}{r}\text { Addresses climate } \\
\text { adaptation }\end{array}$ & Addresses ISM & $\begin{array}{l}\text { Includes coordinated } \\
\text { ISM \& CCA actions }\end{array}$ \\
\hline Climate Change Policy (2012) & Yes & Yes & Yes \\
\hline $\begin{array}{l}\text { Framework for Implementation } \\
\text { of Climate Change Policy } \\
2014-2020 \text { (2013) }\end{array}$ & Yes & No & No \\
\hline Climate Change Act (2017) & Yes & No & No \\
\hline $\begin{array}{l}\text { Technology Needs } \\
\text { Assessment Action Plan and } \\
\text { Project Ideas (2017) }\end{array}$ & Yes & No & No \\
\hline $\begin{array}{l}\text { Nationally Determined } \\
\text { Contribution (2016) }\end{array}$ & Yes & No & No \\
\hline $\begin{array}{l}\text { National Biodiversity Strategy } \\
\text { and Action Plan 2017-2030 } \\
\text { (2015) }\end{array}$ & Partially & Yes & Partially \\
\hline $\begin{array}{l}5^{\text {th }} \text { National Report to CBD to } \\
\text { cover progress on Aichi } \\
\text { Biodiversity Targets } 2010-2020 \\
\text { (2014) }\end{array}$ & No & Yes & No \\
\hline National Forest Policy (2015) & No & Yes & No \\
\hline $\begin{array}{l}\text { National Food Security Policy } \\
\text { (2018) }\end{array}$ & Partially & Partially & No \\
\hline
\end{tabular}

The policy environment for climate adaptation and invasive species management in Pakistan is patchy. No NAP development process has been initiated yet by the Government, despite the 2016 NDC stating this should have started already (Government of Pakistan, 2016). Furthermore, no National Reports to the CBD were available for the last seven years, since 2014. It remains unclear the degree to which older policies and strategies remain a core aspect of the current national Government's approach.

There are very few mentions of the interrelatedness of climate change adaptation and ISM in the national plans and policies in Pakistan. The focus in terms of climate change is primarily on outlining the potential risk associated with the multitude of climate hazards that different regions of Pakistan may face in the coming years and decades, rather than actions which will help to lower risk.

Nonetheless, the Pakistan NBSAP included a target by 2018 to ensure, "The considerations of sustainable agriculture, bio diversification of agro ecosystems, conservation of pollinators and soil biodiversity, wise use of transgenic organisms, and climate change will be incorporated in agriculture policies and plans" (Government of Pakistan, 2015a). However, evidence from the National Food Security Policy suggests this aim has not been fully achieved. Although there are ambitions in the Policy for more sustainable agriculture practices, no specific measures are outlined to achieve these ambitions - the policy calls for greater promotion of climate-smart agriculture (CSA) and integrated pest management (IPM), but does not detail any specific means of achieving this. 
The National Climate Change Policy calls for government agencies to ensure that ecosystem-based adaptation is part of an overall climate change adaptation strategy at all levels (Government of Pakistan, 2012). It also includes the strongest areas of interlinkages between climate change adaptation and ISM, encouraging "empirical research of flora and fauna in the context of their responses to current and historic climate changes", and encouraging the use of primarily indigenous tree species for afforestation activities. But beyond such words of encouragement, no specific measures are set out to achieve these aims in the policy. The Framework for Implementation of the policy which followed fails to address these aspects at all (Government of Pakistan, 2013).

One of the major issues in Pakistan is that measures outlined in the policies and strategies reviewed appear to have had limited implementation. The most recent report to the CBD in 2014 highlighted that more than half (76/134) of all the actions outlined in the 2000 Biodiversity Action Plan had not been implemented at all, with Action 6.6 'Control of exotic invasive alien species' marked as 'not done' (Government of Pakistan, 2014). Similarly, it is difficult to identify that any of the measures outlined in the climate change Technology Needs Assessment have been actioned since publication in 2017, or the Framework for Implementation of the Climate Change Policy since its publication in 2013. However, as no monitoring and reporting documentation for these strategies are publicly available, it is challenging to determine progress with any clarity.

Furthermore, there are inconsistencies both within and between existing policies and plans. For example, the Climate Change Policy (2012) calls for the prioritisation of indigenous tree species for afforestation projects and to prioritise the enhancement of natural ecosystems, but also states it will "Promote farm forestry practices by planting multipurpose fast-growing species to meet the needs for timber, fuel wood and fodder for livestock", which tend to be non-native, grown in monoculture systems, and can be a way that non-native species become established and invasive in new environments. They can also threaten native grasslands which hold greater biodiversity and carbon sequestration potential (Mbaabu, et al., 2020) (Irwin, 2020).

One of the major challenges in implementation of these national strategies and policies is the fragmented nature of roles and responsibilities across different levels of governances and between agencies at each level. As the Government of Pakistan notes in the National Forest Policy, "Unfortunately, each department has a system of management in isolation from other closely related departments/ disciplines. The contemporary scientific knowledge calls for taking a holistic approach or ecosystem approach to better achieve the objective of conservation and sustainable use" (Government of Pakistan, 2015). This siloed approach to managing different natural resource issues in agriculture, forestry, water, and land creates serious difficulties for developing and implementing integrated approaches to NAPs and NBSAPs. One of the key activities of the Action on Invasives programme, led by the Centre for Agriculture and Bioscience International (CABI), was to support dialogue and engagement between agriculture and environment bodies in Pakistan (CABI, 2019). Improvements in cross-sectoral coordination could lead to more effective climate change and ISM strategies.

One promising area for opportunity in Pakistan is that it has not yet developed its NAP, and will likely need to soon draft an updated approach to its 2030 biodiversity targets following the CBD COP15 event in China in 2021. As the Climate Change Authority has overall responsibility for both the NBSAP and the Climate Change policy and the development of any national adaptation plans and strategies, there exists a clear opportunity to ensure that future national strategies are aligned and complementary. Similarly, each of the documents reviewed highlight the importance of Provincial governments in the implementation of national policies, and each makes commitments to improve coordinated action between and across different levels of governance in the country. The National Forest Policy explicitly states that the national Government "shall support provinces in remedial actions including legislation for control of invasive alien species" (Government of Pakistan, 2015). This demonstrates a clear legislative mandate and enabling environment for coordinated, localised action on tackling invasive species and climate change. 


\section{Zambia}

Zambia is highly vulnerable to climate change hazards and impacts from invasive species. Rainfed, subsistence agriculture is the primary sector in Zambia, accounting for more than two-thirds of all employment, and is extremely vulnerable to both acute and chronic (i.e. slow-onset) climate change hazards, particularly droughts, extreme precipitation, and increasing average temperatures, which have been increasing in frequency and severity in recent years (Government of Zambia, 2016) (USAID, 2016). Zambia is ranked as the $136^{\text {th }}$ country in the Global Adaptation Index, with a high vulnerability to climate change impacts, and a low level of 'readiness' to cope with the expected impacts, with vulnerabilities in agriculture and biodiversity highlighted as particularly severe (ND-GAIN, 2021a).

Zambia is also facing significant loss and degradation of ecosystems and biodiversity (ibid). Invasive species have been identified as the second greatest driver of biodiversity loss and degradation after agricultural expansion (Mateba, Mweemba, \& Mwitwa, 2018). The most prominent invasive species in Zambia are water hyacinth, Salvinia molesta (Kariba weed), Tithonia diversifolia, Lantana camara, and Mimosa pigra (Government of Zambia, 2015) (Mateba, Mweemba, \& Mwitwa, 2018). In recent years, Fall Armyworm (FAW) (Spodoptera frugiperda) has become a highly destructive invasive pest in Zambia, causing average losses of 35\% of maize yields in 2018 (CABI, 2018).

The national policies, plans, and strategies for Zambia reviewed for this study are detailed in Table 2:

Table 2: Zambia

\begin{tabular}{|c|c|c|c|}
\hline Document & $\begin{array}{r}\text { Addresses climate } \\
\text { adaptation }\end{array}$ & Addresses ISM & $\begin{array}{l}\text { Includes coordinated } \\
\text { ISM \& CCA actions }\end{array}$ \\
\hline Climate Change Policy (2016) & Yes & No & No \\
\hline $\begin{array}{l}\text { Environmental Management } \\
\text { Act (2011) }\end{array}$ & No & Yes & No \\
\hline Forests Act (2015) & No & No & No \\
\hline $\begin{array}{l}\text { Water Resources Management } \\
\text { Act (2011) }\end{array}$ & Partially & No & No \\
\hline $\begin{array}{l}2^{\text {nd }} \text { National Biodiversity } \\
\text { Strategy and Action Plan }\end{array}$ & Yes & Yes & Yes \\
\hline $\begin{array}{l}7^{\text {th }} \text { National Development Plan } \\
2017-2021\end{array}$ & Partially & No & No \\
\hline $\begin{array}{l}\text { GCF Readiness Support for } \\
\text { NAP Planning (approved 2020) }\end{array}$ & Yes & No & No \\
\hline $\begin{array}{l}\text { Climate Change and Gender } \\
\text { Action Plan (2018) }\end{array}$ & Yes & No & No \\
\hline $\begin{array}{l}\text { Nationally Determined } \\
\text { Contribution (2020) }\end{array}$ & Yes & No & No \\
\hline $\begin{array}{l}\text { Technology Needs } \\
\text { Assessment (2013) }\end{array}$ & Yes & No & No \\
\hline
\end{tabular}


The climate change policy environment is well developed in Zambia, having received external support to develop a number of climate action policies and plans in recent years. It has also recently received approval from the Green Climate Fund (GCF) for support to develop a National Adaptation Plan (GCF, 2020). However, earlier support from 2015-2019 from the UN-FAO to develop an agriculture sectorspecific NAP (UNDP, 2018) (Shula, 2018) (referred to as the 'Ag-NAP') does not appear to have resulted in any clear sectoral adaptation plan, although it is possible that the preparatory work undertaken to date could feed into the development of the overall NAP. It is not evident that issues related to ISM were considered in the consultation processes for the Ag-NAP support project. The GCF Readiness Support proposal highlights that "there is no clarity on the linkages and mandates of the national coordinating structure ... across provincial, district and community level climate actions" (GCF, 2020).

The policy environment for ISM is more limited, with the NBSAP the only strategy to directly address the issues of invasive species in Zambia, although the Environmental Management Act does include a provision for "the prevention of the introduction of, control or eradication of invasive alien species which threaten ecosystems, habitats or species" (Government of Zambia, 2011).

Other policies and strategies do consider biodiversity and ecosystem management more broadly, but several do not consider climate change adaptation or ISM at all, including the National Strategy to Reduce Deforestation and Degradation, Agriculture Lands Act, and Wildlife Act.

This multitude of policies, acts, and plans - often with overlapping areas of responsibility and differing approaches and areas of focus - in addition to several externally-funded climate adaptation projects (UNFCCC, n.d.), creates a complex policy environment in Zambia. As Pardoe et al (2020) highlight, these overlapping and often competing areas of responsibility across different government departments and agencies has resulted in muddled and confused planning and coordination around climate change in Zambia, where "external resources may promulgate turf wars and battles to secure responsibility for the climate change agenda in order to secure access to a funding stream".

Nonetheless, there are several potential areas for greater coordination between climate change adaptation and ISM. The basis for this is already established in the second NBSAP, where the interrelationship between climate change hazards and invasive species hazards is recognised, such as "Rising temperatures are foreseen to negatively affect both crop and livestock productivity ... and associated diseases and pest burdens that are likely to occur as a result" (Government of Zambia, 2015). Moreover, some areas of integrated actions are already outlined, including aims to "Promote the cultivation of land races known to be resilient to pests, diseases and drought", and support for "traditional knowledge, innovations, and practices and local communities" for conservation of biodiversity, climate adaptation, and ISM (ibid). Importantly, the GCF Readiness Support for NAP planning for Zambia notes that the process and outcomes should align with, and support the implementation of, Zambia's $2^{\text {nd }}$ NBSAP strategy (GCF, 2020).

Implementation of the aims set out in the NBSAP appears to have been very limited so far, with no clear evidence that any objectives have been achieved, or that this strategy is a core aspect of government policy-making. For example, the NBSAP includes an objective that, "By 2020, biodiversity values have been integrated into the Seventh National Development Plan (SeNDP), provincial and district development plans and planning processes as well as reporting systems are being incorporated into national accounting, as appropriate" (ibid), but a review of the SeNDP reveals no consideration of biodiversity or ISM, and no evidence that biodiversity reporting systems have been incorporated into national accounting (Government of Zambia, 2017). Implementation is likely weakened by the fragmentation of institutions and departments responsible for implementation across eleven Ministries (Mwitwa, Mwila, \& Mweeba, 2018).

Throughout the documents reviewed for Zambia, there emerged a strong focus on community empowerment. The Climate Change Policy includes measures to "promote stakeholders' participation and partnerships that integrate climate change in natural resources management at all levels" (Government of Zambia, 2016), which is echoed in the GCF Readiness Proposal (GCF, 2020); while the NBSAP calls for the promotion of "platforms for the discussion of scientific biodiversity information exchange and using existing structures such as the Community Based Natural Resources Management Forum" (Government of Zambia, 2015); the SeNDP will "pay particular attention to promoting inclusive participation of women, the youth and other special groups in governance" (Government of Zambia, 
2017), and this is also reflected in the Climate Change Gender Action Plan, which states an intention to "create community climate information centres to enable both urban and rural women farmers to access climate information" (Government of Zambia, 2018). In addition, the Protection of Traditional Knowledge Act includes measures to "confer rights on traditional communities, individuals and groups and promote the conservation and sustainable utilisation of the country's biodiversity resources" (Government of Zambia, 2016a).

\section{Ghana}

Ghana is considered extremely vulnerable to climate change impacts, including droughts, floods, rising sea levels, loss of biodiversity, desertification, and shortened growing seasons. The north of the country and central 'transitional zone' are particularly vulnerable to climate change hazards (Government of Ghana, 2010a). Ghana is ranked as the $109^{\text {th }}$ country in the Global Adaptation Index, with a high vulnerability to climate change impacts, and a low level of 'readiness' to cope with the expected impacts. It is the highest-ranked country of those reviewed for this study, but is considered particularly vulnerable to climate change impacts in the agriculture sector (ND-GAIN, 2021).

Droughts are a major problem for the northern and coastal savannahs, with increasing significance for the transitional zone. Agriculture is the primary sector in Ghana, and the most vulnerable to climate change impacts. Rising temperatures and variable precipitation threaten both cocoa farmers in the south, and subsistence farmers in the north, while land degradation desertification is an increasing problem in the transitional zone (Government of Ghana, 2010a).

Climate change impacts are also causing issues related to invasive species and biodiversity. Nearly 300 indigenous crop varieties are nearing extinction, land degradation is weakening ecosystem defences against invasive species, and natural carbon sinks are being lost (Government of Ghana, 2016). The most common and damaging invasive species include Fall Armyworm (Spodoptera frugiperda), Bactrocera dorsalis (fruit fly), Broussonetia papyrifera (Paper Mulberry), Chromolaena odorata (Acheampong weed), and Eichhornia crassipes (water hyacinth) (CABI \& EPA, 2020). The proliferation of these invasive species has led to significant loss of native biodiversity resulting in the degradation of ecosystems and a decline in ecological services (Government of Ghana, 2016).

The national policies, plans, and strategies for Ghana reviewed for this study are detailed in Table 3:

\section{Table 3: Ghana}

\begin{tabular}{|l|r|r|r|}
\hline Document & $\begin{array}{r}\text { Addresses climate } \\
\text { adaptation }\end{array}$ & Addresses ISM & $\begin{array}{r}\text { Includes coordinated } \\
\text { ISM \& CCA actions }\end{array}$ \\
\hline $\begin{array}{l}\text { Ghana's National Adaptation } \\
\text { Plan Framework (2018) }\end{array}$ & Yes & No & Partially \\
\hline $\begin{array}{l}\text { Climate Change Master Plan: } \\
\text { 2015-2020 (2015) }\end{array}$ & Yes & Partially & Partially \\
\hline Climate Change Policy (2012) & Yes & No & No \\
\hline $\begin{array}{l}\text { Ghana National REDD+ } \\
\text { Strategy (2015) }\end{array}$ & No & Yes & No \\
\hline $\begin{array}{l}\text { National Environmental Policy } \\
\text { (2012) }\end{array}$ & No & Yes & No \\
\hline $\begin{array}{l}\text { National Biodiversity Strategy } \\
\text { and Action Plan (2016) }\end{array}$ & No & & \\
\hline
\end{tabular}




\begin{tabular}{|l|r|r|r|}
\hline $\begin{array}{l}\text { National Climate Change } \\
\text { Adaptation Strategy 2010-2020 } \\
\text { (2010) }\end{array}$ & Yes & No & No \\
\hline $\begin{array}{l}\text { Nationally Determined } \\
\text { Contribution (2015) }\end{array}$ & No & No & No \\
\hline $\begin{array}{l}\text { Environmental Sanitation } \\
\text { Policy (1999) }\end{array}$ & No & Partially & No \\
\hline $\begin{array}{l}\text { National Spatial Development } \\
\text { Framework 2015-2035 (2015) }\end{array}$ & Yes & Partially & No \\
\hline $\begin{array}{l}\text { National CSA \& Food Security } \\
\text { Action Plan (2016-2020) }\end{array}$ & No & Yes & Partially \\
\hline $\begin{array}{l}\text { National Invasive Species } \\
\text { Strategy and Action Plan for } \\
\text { Ghana 2020-2030 (2020) }\end{array}$ & & & No \\
\hline
\end{tabular}

Ghana has a well-developed policy base for climate change adaptation with several specific policies, plans, and strategies. Climate change considerations are also reasonably well mainstreaming into other sectoral policies, reflecting the significant hazard climate change poses to Ghana now and in the coming years. National coordination on climate adaptation action has been enhanced through the establishment of a specific Unit within the Environmental Protection Agency, as well as a National Climate Change Committee hosted by the Ministry of Environment, which coordinates action with climate change departments in other key ministries including forestry and agriculture, while the National Development Planning Commission (NDPC) coordinates district-level adaptation planning (Antwi-Agyei, Nkrumah, \& Amoah, 2018) (Government of Ghana, 2018).

Policies addressing ISM are less prominently integrated into national and local planning processes, although the recently formulated National Invasive Species Strategy and Action Plan (NISSAP) aims to address this as one of its core aims (CABI \& EPA, 2020). The National Environmental policy highlights the growing threat of aquatic weeds in the Volta River Basin, among other issues (Government of Ghana, 2012), but does not set out specific measures for tackling invasive species risks; while the Environmental Sanitation Policy includes only a declaration that, "District Assemblies shall make arrangements, both directly and through the private sector, for the effective and continuous control of insect vectors and pests" (Government of Ghana, 2010), with no specific measures to support this at a national level.

The NBSAP includes three targeted short term (2016-2020) objectives for ISM, including developing a national ISM system by 2017, a communications protocol for a pest early warning system (EWS) by 2018, and a specific ISM policy and strategy to be developed and implemented, also by 2018 (Government of Ghana, 2016). The latter target has been developed in the form of the NISSAP, while some action has been taken on the other two targets ${ }^{3}$. The NBSAP highlights the challenges of implementation, stating that, "Although biodiversity issues are captured in the National Development Agenda, the level of coordination within and among the various actors (public, private and civil society) is generally very poor ... Additionally, many of the institutions involved in biodiversity governance, at both the national and sub-national levels, have weak capacities."

${ }^{3}$ Confirmed through a comment from the Ghana Environmental Protection Agency 
There are minimal interlinkages between ISM and climate adaptation in the documentation reviewed. Where it does exist, it is primarily at a situation analysis level - identifying the relationships between climate change and pest risks, for example - but not at the action and implementation level, such as in the NISSAP.

There are overlaps in approaches to sustainable ecosystem management and governance, which may present opportunities for integrating coordinated action on ISM and building adaptive capacity to climate change, particularly where there are common implementing responsibilities at decentralised levels. The NAP Framework states that "adopting an ecosystem approach will align Ghana's NAP process with [the] CBD Strategy" (Government of Ghana, 2018). As the NAP process is being led by the Environmental Protection Agency, which also oversees actions on ISM, and is developing a sectoral NAP for agriculture (NAP Global Network, 2021), there is significant scope for high-level coordination and integration of approaches.

Meanwhile, the National Climate Change Master Plan calls for "more emphasis on community-based natural resource management; this, with appropriate economic incentive measures, will result in true ecosystem-based adaptation"; and to "Develop intensive community monitoring systems for disturbances such as degradation, wildfire and pest infestation to maintain the integrity of forest ecosystems" (Government of Ghana, 2015).

In a similar vein, the National Environmental Policy includes an objective to "encourage involvement of local communities inside and outside protected areas in the planning and management of such areas" (Government of Ghana, 2012). The NISSAP also includes local capacity development and prioritising and ecosystem-based approach to ISM (CABI \& EPA, 2020).

An additional area of commonality is the strong focus throughout the national strategies on food security. While none of the specific food security measures included in the strategies make an explicit connection between enhancing adaptive capacity to climate change and ISM, both are critical issues which can severely undermine food security, as is recognised in the National Climate-Smart Agriculture and Food Security Action Plan (Essegbey, Nutsukpo, \& Zougmoré, 2015).

\section{Kenya}

Climate Change is a major threat to people's livelihoods and the economy in Kenya. Acute hazards including severe drought, flash floods, extreme winds, as well as rising temperatures, all pose serious dangers. Kenya is already facing these threats, and it is anticipated that these impacts will become increasingly acute by 2030. In addition, the National Climate Change Action Plan highlights the risks of slow-onset hazards, noting that, "Rainfall patterns have changed, with the long rainy season becoming shorter and dryer and the short rainy season longer and wetter. Overall annual rainfall remains low, [and] the long rains have been continuously declining in recent decades" (Government of Kenya, 2018). Kenya is ranked as the joint $152^{\text {nd }}$ country in the Global Adaptation Index (level with Pakistan), with a high vulnerability to climate change impacts, and a low level of 'readiness' to cope with the expected impacts (ND-GAIN, 2021).

Invasive species also pose growing threats to Kenya's economy and food security, with nearly 100 nonnative species identified across the country (Government of Kenya, 2021). In particular, the damage to crops caused by Fall Armyworm since 2016 has been devastating for smallholder farmers (Government of Kenya, 2019). Furthermore, the proliferation of non-native aquatic flora and fauna (e.g. water hyacinth) threatens sustainability of the indigenous species and the proper functioning of ecosystem services (Government of Kenya, 2017). Invasive plants such as Prosopis juliflora and Opuntia stricta (a cactus) have grown uncontrollably from their initial areas of introduction and wreaked havoc in grazing lands and have led to serious landscape degradation (Mbaabu, et al., 2020), while more recently the 
noxious weed, Parthenium hysterophorus, has spread rapidly, threatening native biodiversity (Government of Kenya, 2021).

Agriculture remains the dominant economic sector in Kenya, contributing to one third of national GDP, and an additional $27 \%$ GDP through associated value chains and services. It also employs over $70 \%$ of the rural population across the country (Government of Kenya, Agriculture Sector Transformation and Growth Strategy 2019-2029, 2019). Over 7.2 million people who live in the arid and semi-arid areas (ASALs) are chronically food insecure, primarily due to the impacts of climate-driven hazards, particularly drought (ibid).

The national policies, plans, and strategies for Kenya reviewed for this study are detailed in Table 4:

\section{Table 4: Kenya}

\begin{tabular}{|c|c|c|c|}
\hline Document & $\begin{array}{r}\text { Addresses climate } \\
\text { adaptation }\end{array}$ & Addresses ISM & $\begin{array}{l}\text { Includes coordinated } \\
\text { ISM \& CCA actions }\end{array}$ \\
\hline $\begin{array}{l}\text { Climate Smart Agriculture } \\
\text { Strategy 2017-2020 (2017) }\end{array}$ & Yes & Partially & Yes \\
\hline $\begin{array}{l}\text { Agriculture Sector } \\
\text { Development Strategy 2010- } \\
2020 \text { (2010) }\end{array}$ & Partially & Yes & No \\
\hline $\begin{array}{l}\text { Agricultural Sector } \\
\text { Transformation and Growth } \\
\text { Strategy 2019-2029 (2019) }\end{array}$ & Yes & Yes & No \\
\hline $\begin{array}{l}\text { National Adaptation Plan 2015- } \\
2030 \text { (2016) }\end{array}$ & Yes & No & No \\
\hline $\begin{array}{l}\text { National Climate Change } \\
\text { Action Plan 2018-2022 }\end{array}$ & Yes & No & No \\
\hline Climate Change Act (2016) & Yes & No & No \\
\hline $\begin{array}{l}\text { National Climate Change } \\
\text { Framework Policy (2016) }\end{array}$ & Yes & No & No \\
\hline Community Land Act (2016) & No & Partially & No \\
\hline Plant Protection Bill (2020) & No & Yes & No \\
\hline $\begin{array}{l}\text { Technology Needs } \\
\text { Assessment: Technology } \\
\text { Action Plan (Adaptation) (2013) }\end{array}$ & Yes & No & No \\
\hline $\begin{array}{l}\text { Kenya Vision } 2030 \text { - Third } \\
\text { Medium-term Plan 2018-2022 } \\
\text { (2019) }\end{array}$ & Yes & Partially & No \\
\hline $\begin{array}{l}\text { Kenya Nationally Determined } \\
\text { Contribution (2015) }\end{array}$ & Yes & No & No \\
\hline $\begin{array}{l}\text { TWENDE: Ecosystem Based } \\
\text { Adaptation in Kenya's Arid and }\end{array}$ & Yes & Partially & No \\
\hline
\end{tabular}




\begin{tabular}{|l|r|r|r|}
\hline $\begin{array}{l}\text { Semi-Arid Rangelands - GCF } \\
\text { proposal (approved 2019) }\end{array}$ & No & Yes & No \\
\hline $\begin{array}{l}\text { National Biodiversity Strategy } \\
\text { and Action Plan (2000) }\end{array}$ & No & Yes & No \\
\hline $\begin{array}{l}\text { National Biodiversity Strategy } \\
\begin{array}{l}\text { and Action Plan 2019-2030 } \\
\text { (draft, 2018) }\end{array}\end{array}$ & Partially & Yes & No \\
\hline $\begin{array}{l}6^{\text {th }} \text { National Report for the CBD } \\
(2021)\end{array}$ & & & \\
\hline
\end{tabular}

The policy environment for climate change adaptation, ISM, and natural resource management is highly complex. There are multiple areas of overlapping policies, acts, strategies, and plans, which are further complicated by the devolution of many areas of responsibility to county governments in recent years. There are so many overlapping and competing objectives that it is difficult to identify which are current and take precedence.

This is made even more challenging by there being no clear synergies and complementarity between different strategies - for example the Agriculture Sector Transformation and Growth Strategy 2019-2029 (Government of Kenya, 2019) includes many references to CSA, but makes no mention of the Climate Smart Agriculture Strategy 2017-2026. As can also be identified with these two strategies as an example, there are inconsistent and overlapping implementation period for many plans and strategies.

This is further exemplified by the Kenya Vision 2030 Third Medium Term Plan (MTP3) for 2018-2022 calling for the development of a CSA strategy - despite one already existing - and listing a range of potential policies and acts, including some related to ISM, but failing to note that similar strategies already exist (Government of Kenya, 2018a). Moreover, the MTP3 does not directly consider the many plans, policies, strategies, and large national programmes which existed at the time of its development when setting out plans for the implementation period and the prioritisation of objectives. As the Kenya Vision 2030 is the overarching guiding document for national development planning, this creates an incoherent approach for issues related to climate change adaptation, ISM, and other related areas.

A new NBSAP covering the period 2019-2030 was drafted in 2018, but has not progressed beyond its draft form and has not been officially ratified or submitted to the CBD (NEMA, n.d.). The only official NBSAP submitted to the CBD is the first strategy from the year 2000. The 2019-2030 draft recognises the interrelationship between climate change and biodiversity as part of the situation analysis, and the need for coordinated action on both issues. But it does not set out a clear means of achieving coordinated action, beyond stating that the NBSAP should be a 'living document' and regularly updated to reflect the changing climatic conditions (Government of Kenya, 2018). It also has surprisingly little related to ISM, despite this being the primary strategy for addressing invasive species issues in Kenya.

Weak implementation and poor coordination within and between different areas of government and across policies are highlighted as major challenges in several documents. The CSA Strategy notes that, "Weak polices, legislations, enforcement, and overlap of mandates among institutions involved in regulation, coupled with poor coordination and collaboration among institutions and stakeholders in climate smart agriculture (CSA), have contributed to the country's inability to effectively address [climate] vulnerability" (Government of Kenya, 2017).

Commenting on the myriad national and local bodies with responsibilities for controlling invasive pests, the Agriculture Sector Development Strategy 2010-2020 notes that, "With so many bodies, there is the risk of inefficiency, duplication of effort and over-regulation of the agricultural sector" (Government of Kenya, 2010). This was echoed in a review of the ISM system in Kenya in 2019 (Williams \& Constantine, 
2019). Moreover, the Plant Protection Bill (which is still under development) will establish a new national Plant Health Standing Technical Committee, a new National Plant Health Emergency Response Unit, and two new Plant Health Protection Funds - one national, one county-level (Government of Kenya, 2020). But there has been improved dialogue on ISM between national government entities, businesses, agricultural organisations, and research organisations in recent years (Williams \& Constantine, 2019).

Most of the documents reviewed consider the impacts and challenges of both climate change and ISM, particularly in the situation analysis sections, and most also set out plans to address both issues to a greater or lesser extent. However, coordinated action and processes to address both adaptation ISM are only detailed in the CSA Strategy which highlights the importance of natural resource management strategies that consider the range of biotic and abiotic stresses and hazards in agriculture, and mechanisms for addressing natural resources use and governance conflicts which may emerge (Government of Kenya, 2017). The Agriculture Sector Transformation and Growth Strategy for 20192029 sets out the dual challenges of ISM and climate change in the opening paragraph, but proceeds to treat them as separate issues, although it does state that developing early warning systems will be a 'flagship' strategy for each issue, so there is potential for some integration.

As a result of devolution, many areas of implementation of these national approaches lie with the County governments. While this adds considerable complexity to the national picture, with County governments needing to develop their own legislation to enact these policies, and often lacking the capacity to do so (Government of Kenya, 2021), it does also open up opportunities for localised action and improved coordination between ISM and climate change adaptation. For example, community-based natural resource management initiatives in Kenya seek to empower communities to enable them share in the rights and responsibilities of management and utilization of natural resources with the government (ibid).

\section{Analysis}

This section provides analysis the findings from across each of the four countries in relation to the three research questions.

\section{What are the commonalities and differences in approaches in policies?}

While there is some mention of ISM in national climate plans and policies, they are a minor aspect and given comparatively little attention. Similarly, climate change is rarely mentioned in ISM-specific documents, but it is in terms of broader biodiversity plans. Moreover, ISM units/specialists are not listed as being stakeholders in any of the countries' climate change planning policies or stakeholder engagement processes. Climate change is seen as something that can and should be mainstreamed (to a greater or lesser degree) across most sectors and ministries, whereas ISM is typically found in agriculture, forestry, environment, and trade, and delegated to specific specialist units.

Moreover, all climate policies and national development strategies, as well as some invasive species management plans, include ambitions to improve gender equality and women's empowerment, and engagement of youth.

Policies in Kenya and Zambia in particular focus on the role of local governance systems in interpreting and implementing the national frameworks and policies, and highlight the need for inclusive consultative processes to achieve this. Policies in Ghana also mention the role of local governance systems, but to a lesser degree; while in Pakistan the differentiated areas of governance between national and regional governments are clearly outlined, but there is less guidance provided for regional governments compared to Kenya.

Pakistan, Kenya, and Zambia all place a great emphasis in both climate and ISM related policies and strategies on building resilience to biotic and abiotic stresses, and at least conceptually build action plans around this theme. In Ghana, policies generally have a much greater focus on economic growth opportunities. 


\section{To what degree do each of these policy areas consider both adaptation and ISM?}

Across all four countries, the documents reviewed often consider both climate change adaptation and invasive species management in the situational analysis, particularly in relation to food security. But aside from some minor activities, there is little consideration of the specific technical responses which achieve win-win results for both climate adaptation and ISM, nor of processes and governance systems to act in coordinated ways to address these two major food security threats.

Decentralised and local governance mechanisms are prioritised by ISM strategies, climate adaptation plans, forestry and biodiversity management policies, as well as national development plans. There appear to be strong opportunities for more coordinated efforts at this 'meso' level for natural resource governance and planning which could address both ISM and climate adaptation simultaneously, with the same cohort of stakeholders, and possibly also with common budget allocations.

The greatest area of interlinkages is in natural resource management, including spatial planning, land management, conservation, and sustainable agro-industry SMEs (e.g. manufacturing and retailing lowrisk plant health products, including biopesticides and biofertilizers), as well as in integrated ecosystembased adaptation (EbA) and Community-based Adaptation ( $\mathrm{CbA}$ ) technical approaches. Guidance from the FAO outlines the ways in which locally-led EbA approaches can be highly effective in enhancing adaptive capacity, particularly in agriculture, while simultaneously supporting the resilience and biodiversity of natural ecosystems through the promotion of native species and ISM (FAO, 2020a).

\section{What are the opportunities for more integrated approaches? And what benefits would these bring?}

The greatest area of potential for technical interlinkages lies in the development and promotion of early warning systems. In national policies, these are primarily focused on weather-related extreme events (flooding, drought, cyclones, and landslides), but there is scope to extend this to pest and disease outbreaks, and to address the root-causes of climate vulnerability which exacerbate risks, such as invasive plants depleting water availability and destabilising soils.

Protecting ecosystems from the threats of climate change and invasive species is crucial to supporting their proper functioning and maintaining biodiversity. Recent moves to integrate the value of ecosystems and their services into economic accounting - such as the System of Environmental-Economic Ecosystem Accounting, launched in 2021 by the UN (2021) - could act as a framework for national governments for integrated approaches to protecting vulnerable ecosystems, and ensuring sufficient budgetary support is allocated to related activities.

Given both ISM and climate adaptation issues and solutions are both highly variable and contextdependent, the focus on coordinated action at the meso-level of governance appears to be a 'sweet spot' for integrated planning and action. The need to value local perspective in invasive species management and climate adaptation is crucial to developing appropriate strategies which minimize trade-offs (Tebboth, Few, Assen, \& Degefu, 2020).

Approaches supporting local governance would align well to the recently-launched 'principles of locallyled adaptation' (Soanes, et al., 2021) which have been endorsed by more than 40 governments (IIED, 2021), and the renewed focus on 'nature-based solutions' (NbS) which will be prioritised at COP26 in 2021 (UNFCCC, 2020). Martin et al (2021) found that critical enablers of NbS include coordination across multiple scales of governance, participatory engagement of local stakeholders, and financing community-led implementation of prioritised activities.

The policy support for improved women's empowerment and economic opportunities for youth could link to ISM practices too, as a common area of work to empower women in agriculture and forestry in managing the land and associated activities in a sustainable, climate-resilient way, and enhance economic empowerment for youth through associated business opportunities. 


\section{Conclusions}

This study has found that there is currently minimal integration between climate change adaptation and invasive species management policy and strategy areas, and little overlap in implementation systems and technical approaches. It has also identified that sub-national planning and governance systems are an optimal area for increased harmonization of policy and practice to facilitate locally-led climate adaptation and area-specific responses to invasive species hazards.

Although these two issues of biotic and abiotic stresses both pose serious threats now and in the future to food security, ecosystem integrity, and water availability for the same stakeholders - particularly smallholder farmers - they are treated as separate issues in current policy and practice in the four countries studied. Ultimately, there is little evidence that there would be significant avoidance of duplicated activities through more coordinated action and strategies; but there may be greater policy coherence - and potential for greater financing for ISM - through climate adaptation funding, particularly in the areas of natural resource management, and early warning systems.

As countries look to develop new biodiversity action plans, and submit enhanced climate action NDCs to meet Paris Agreement goals, there is an opportunity for more coordinated policy approaches and implementation strategies for these two intrinsically linked areas of natural resources management, which could be underpinned by frameworks such as the UN System of Environmental-Economic Ecosystem Accounting. Figure 1 demonstrates a potential process for enhanced coordination in invasive species management and climate change adaptation planning.

Figure 1: Coordinated policy development process
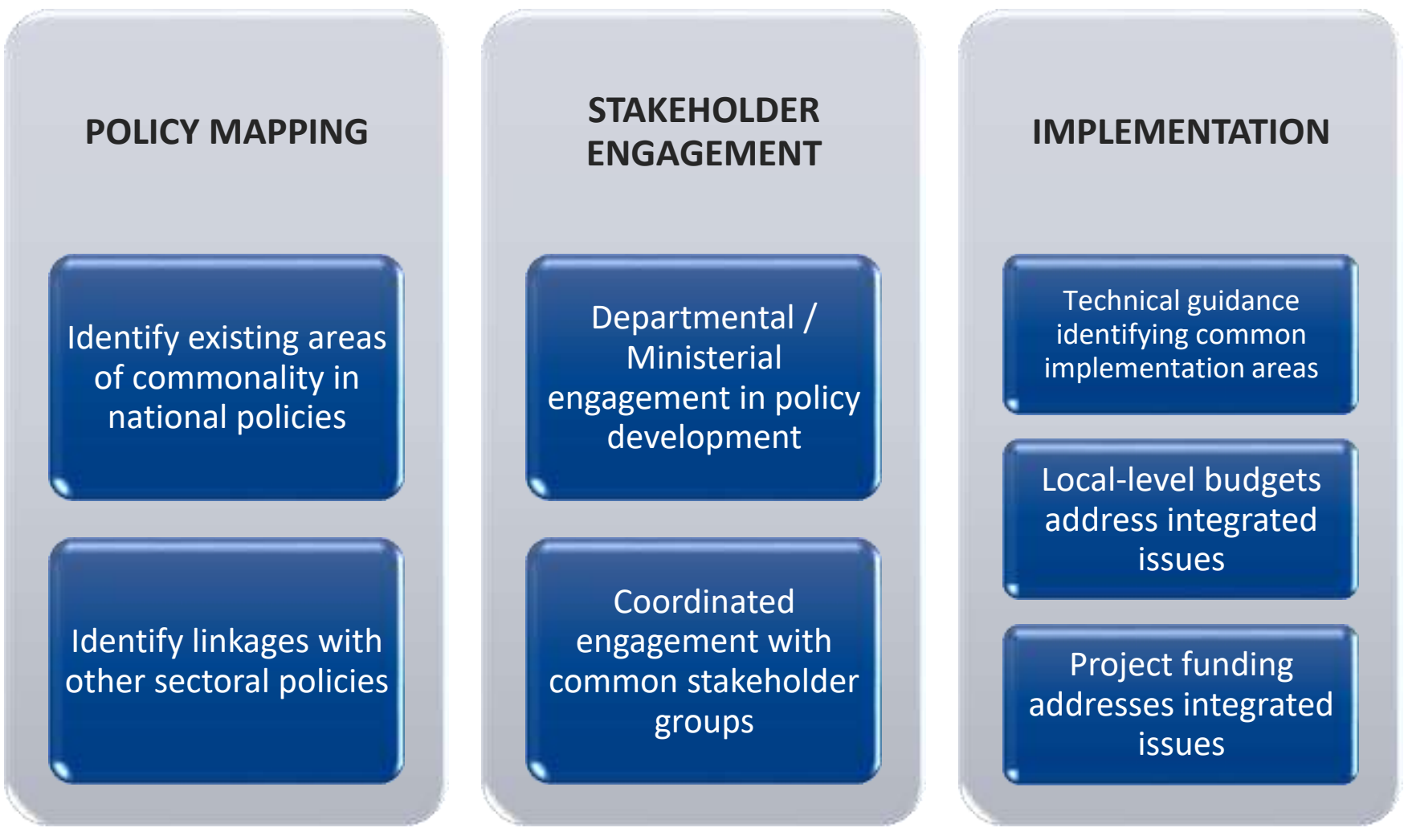


\section{References}

Antwi-Agyei, P., Nkrumah, K., \& Amoah, A.-B. (2018). Ghana's Vision for National Adaptation Planning. Retrieved March 19, 2021, from NAP Global Network:

https://napglobalnetwork.org/2018/09/ghanas-vision-for-national-adaptation-planning/

Asif, M. (2018, December 7). Alien Invasive Plant Species in Pakistan and their Control through Genomics. Retrieved March 16, 2021, from https://medium.com/@muhammad.asif88/alieninvasive-plant-species-in-pakistan-and-their-control-through-genomics-f2d998dbdf78

Bahadur, A., Peters, K., Wilkinson, E., Pichon, F., Gray, K., \& Tanner, T. (2015). The 3 As: Tracking Resilience Across BRACED. London: ODI. Retrieved from https://www.odi.org/sites/odi.org.uk/files/odi-assets/publications-opinion-files/9812.pdf

CABI. (2018). Fall Armyworm: Impacts and Implications for Africa Evidence Note Update (Summary Version). Wallingford, UK: CABI. Retrieved from https://ckan.cabi.org/data/dataset/559d4087f8dc-4d4f-b01c-e12023fb3d3f/resource/2138ca99-d8d1-4fe9-8415-

5fbc417bafe4/download/faw_evidencenote_summary_2018.pdf

CABI. (2019). Action on Invasives Annual Report 2019. Wallingford, UK: CABI. Retrieved from https://www.cabi.org/wp-

content/uploads/Action_on_Invasives_Annual_Report_2019_PUBLIC.pdf

CABI, \& EPA, G. (2020). National Invasive Species Strategy and Action Plan for Ghana 2020-2030. Accra: Government of Ghana.

Cavicchioli, R., Ripple, W. J., \& Webster, N. S. (2019, June 18). Scientists' warning to humanity: microorganisms and climate change. Nature Reviews Microbiology, 17, 569-586. doi:https://doi.org/10.1038/s41579-019-0222-5

CBD. (2020). Aichi Targets. Retrieved February 20, 2021, from Aichi Targets: https://www.cbd.int/sp/targets/

CBD. (2020). Global Biodiversity Outlook 5. Montreal: CBD.

CBD. (2020, February 22). National Biodiversity Strategies and Action Plans (NBSAPS). Retrieved February 20, 2021, from National Biodiversity Strategies and Action Plans (NBSAPs): https://www.cbd.int/nbsap/

CBD. (2020). Preparation of the post-2020 global biodiversity framework: conclusions of the Work Group. Montreal: CBD. Retrieved from https://www.cbd.int/doc/recommendations/wg202002/wg2020-02-rec-01-en.pdf

CBD. (n.d.). What are Invasive Alien Species? Retrieved February 20, 2021, from What are Invasive Alien Species?: https://www.cbd.int/invasive/WhatarelAS.shtml

Essegbey, G., Nutsukpo, D., \& Zougmoré, R. (2015). National Climate-Smart Agriculture and Food Security Action Plan of Ghana (2016-2020). CCAFS, MoFA. CGIAR. Retrieved from http://extwprlegs1.fao.org/docs/pdf/gha169288.pdf

FAO. (2020). Strategic framework for the International Plant Protection Convention (IPPC) 2020-2030. Rome: FAO. Retrieved from https://assets.ippc.int/static/media/files/publication/en/2020/12/IPPC_Strategic_Framework_2020 -2030_2020-12-09.pdf

FAO. (2020a). National Adaptation Plans - An entry. Rome: FAO. Retrieved from http://www.fao.org/3/ca9541en/ca9541en.pdf

GCF. (2020). GCF Readiness Support for NAP Planning. Retrieved from https://www.greenclimate.fund/sites/default/files/document/zambia-nap-gwpo.pdf 
GCF. (2020, June 3). GCF Support for NAPs. Retrieved February 20, 2021, from GCF Readiness

Support: https://www.greenclimate.fund/readiness/naps

Government of Ghana. (2010). Environmental Sanitation Policy.

Government of Ghana. (2010a). National Climate Change Adaptation Strategy 2010-2020. UNDP.

Retrieved from https://www.adaptation-

undp.org/sites/default/files/downloads/ghana_national_climate_change_adaptation_strategy_ncc as.pdf

Government of Ghana. (2012). National Environmental Policy.

Government of Ghana. (2015). Ghana National Climate Change Master Plan Action Programme for Implementation: 2015-2020.

Government of Ghana. (2016). Ghana National Biodiversity Strategy and Action Plan.

Government of Ghana. (2018). Ghana's National Adaptation Plan Framework.

Government of Ghana. (2020, November 17). National Development Monitor. Retrieved from https://s3us-west-2.amazonaws.com/new-ndpc-

static1/CACHES/IMAGES/2020/11/17/National\%20Development\%20Monitor.pdf

Government of Kenya. (2010). Kenya Agriculture Sector Development Strategy 2010-2020.

Government of Kenya. (2017). Kenya Climate Smart Agriculture Strategy 2017-2026.

Government of Kenya. (2018). Kenya National Biodiversity Strategy and Action Plan 2019-2030 (draft).

Retrieved from http://meas.nema.go.ke/cbdchm/download/Meas/Biodiversity/Plans-and-

Strategies/KENYA-NBSAPFINAL-DRAFT.pdf

Government of Kenya. (2018). National Climate Change Action Plan 2018-2022.

Government of Kenya. (2018a). Kenya Vision 2030: Third Medium Term Plan 2018-2022. Retrieved from http://vision2030.go.ke/wp-content/uploads/2019/01/THIRD-MEDIUM-TERM-PLAN-20182022.pdf

Government of Kenya. (2019). Agriculture Sector Transformation and Growth Strategy 2019-2029.

Retrieved from

file://C:/Users/caseyj/Downloads/Agriculture\%20Sector\%20Transformation\%20and\%20Growth\% 20Strategy-Full-Version.pdf

Government of Kenya. (2020). Plant Protection Bill.

Government of Kenya. (2021, March 02). 6th National Report for the Convention on Biological Diversity.

CBD. Retrieved March 19, 2021, from https://s3.amazonaws.com/pdf-cache-prod/chm/253902-9en.pdf

Government of Pakistan. (2012). National Climate Change Policy.

Government of Pakistan. (2013). Framework for Implementation of Climate Change Policy 2014-2020.

Government of Pakistan. (2014). 5th National report to CBD to cover progress on ABT 2010-2020.

Government of Pakistan. (2015). National Forest Policy.

Government of Pakistan. (2015a). Pakistan National Biodiversity Strategy and Action Plan 2017-2030.

Government of Pakistan. (2016). Intended Nationally Determined Contribution. Retrieved from https://www4.unfccc.int/sites/ndcstaging/PublishedDocuments/Pakistan\%20First/Pak-INDC.pdf

Government of Pakistan. (2018). National Food Security Policy.

Government of Zambia. (2011). Environmental Management Act.

Government of Zambia. (2015). Zambia's Second National Biodiversity Strategy and Action Plan.

Government of Zambia. (2016). National Policy on Climate Change. Ministry of lands, Natural

Resources. 
Government of Zambia. (2016a). Protection of Traditional Knowledge, Genetic Resources, and Expressions of Folklore Act.

Government of Zambia. (2017). 7th National Development Plan 2017-2021. Retrieved from https://zambiaembassy.org/sites/default/files/documents/7NDP_final_07-06-17.pdf

Government of Zambia. (2018). Climate Change Gender Action Plan.

Green, E. J., Buchanan, G. M., Butchart, S. H., Chandler, G. M., Burgess, N. D., Samantha, H. L., \& Gregory, R. D. (2019, April 2). Relating characteristics of global biodiversity targets to reported progress. Conservation Biology. doi:https://doi.org/10.1111/cobi.13322

Grist, N. (2014). Transformative adaptation in Africa's Agriculture. London: ODI. Retrieved from https://www.odi.org/sites/odi.org.uk/files/odi-assets/publications-opinion-files/9367.pdf

Heeb, L., Jenner, E., \& Cock, M. J. (2019, June 1). Climate-smart pest management: building resilience of farms and landscapes to changing pest threats. Journal of Pest Science, 92, 951-969. doi:https://doi.org/10.1007/s10340-019-01083-y

IIED. (2021, January 25). Forty governments and leading institutions commit to support locally led climate adaptation. Retrieved March 19, 2021, from IIED: https://www.iied.org/forty-governmentsleading-institutions-commit-support-locally-led-climate-adaptation

IPCC. (2014). Fifth Assessment Report. Geneva: IPCC. Retrieved from https://www.ipcc.ch/site/assets/uploads/2018/02/WGIIAR5-AnnexII_FINAL.pdf

IPPC. (1999). International Plant Protection Convention (new revised text). Rome: IPPC. Retrieved from https://www.ippc.int/en/publications/131/

IPPC. (2019). Plant Health and Environmental Protection. Rome: FAO. Retrieved from http://www.fao.org/3/ca3279en/CA3279EN.pdf

IPPC. (2021). Adopted International Standards for Phytosanitary Measures. Rome: IPPC. Retrieved from https://www.ippc.int/en/publications/626/

IPPC. (2021). Plant health and climate change. Rome: FAO. Retrieved from http://www.fao.org/3/cb3764en/cb3764en.pdf

IPPC. (2021a). Plant health and climate change. Rome: FAO. Retrieved from http://www.fao.org/3/cb3764en/cb3764en.pdf

Irwin, A. (2020, July 01). Global tree pledge frenzy threatens ancient grasslands. SciDevNet. Retrieved March 31, 2021, from https://www.scidev.net/global/features/global-tree-pledge-frenzy-threatensancient-grasslands/

Lonsdale, K., Pringle, P., \& Turner, B. (2015). Transformative adaptation: what it is, why it matters \& what is needed. Oxford: University of Oxford. Retrieved from https://ukcip.ouce.ox.ac.uk/wpcontent/PDFs/UKCIP-transformational-adaptation-final.pdf

Martin, J. G., Scolobig, A., Linnerooth-Bayer, J., Lie, W., \& Balsiger, J. (2021, February 11). Catalyzing Innovation: Governance Enablers of. Sustainability, 13. doi:https://doi.org/10.3390/su13041971

Mateba, J., Mweemba, B., \& Mwitwa, J. (2018). Key drivers of biodiversity loss in Zambia. Retrieved from https://www.biodiversityfinance.net/sites/default/files/content/knowledge_products/BIOFIN\%20ZM \%20PB\%20\%233-Drivers\%20of\%20biodiversity\%20loss\%20in\%20Zambia.pdf

Mbaabu, P., Olago, D., Gichaba, M., Eckert, S., Eschen, R., Oriaso, S., . . Schaffner, U. (2020, November 24). Restoration of degraded grasslands, but not invasion by Prosopis juliflora, avoids trade-offs between climate change mitigation and other ecosystem services. Scientific Reports, 10(20391). doi:https://doi.org/10.1038/s41598-020-77126-7

Mwitwa, J., Mwila, R., \& Mweeba, B. (2018). Policy and Institutional Review for biodiversity conservation in Zambia. Retrieved from

https://www.biodiversityfinance.net/sites/default/files/content/knowledge_products/BIOFIN\%20ZM 
$\% 20 \mathrm{~PB} \% 20 \% 231-$

Policy\%20and\%20Institutional\%20Review\%20for\%20biodiversity\%20conservation\%20in\%20Za mbia\%5B1\%5D.pdf

NAP Global Network. (2021). Resilience in Action: Five years of supporting National Adaptation Plan

(NAP) processes. IISD. Retrieved from https://www.napglobalnetwork.org/wp-

content/uploads/2021/01/napgn-en-2020-Resilience-in-Action.pdf

ND-GAIN. (2021). Notre Dame Adaptation Initiative. Notre Dame, Indiana, USA. Retrieved March 31, 2021, from https://gain-new.crc.nd.edu/country/kenya

ND-GAIN. (2021). Notre Dame Global Adaptatio Initiative. Notre Dame, Indiana, USA. Retrieved March 31, 2021, from https://gain-new.crc.nd.edu/country/ghana

ND-GAIN. (2021). Notre Dame Global Adaptation Initiative. Notre Dame, Indiana, USA. Retrieved March 31, 2021, from https://gain-new.crc.nd.edu/country/pakistan

ND-GAIN. (2021a). Notre Dame Global Adaptation Initiative. Notre Dame, Indiana, USA. Retrieved March 31, 2021, from https://gain-new.crc.nd.edu/country/zambia

NEMA, N. E. (n.d.). National Strategy. Retrieved March 19, 2021, from Biodiversity Clearing house Mechanism National Focal Point Director General: http://meas.nema.go.ke/cbdchm/nationalstrategy/

Pardoe, J., Vincent, K., Conway, D., Archer, E., Dougill, A. J., Mkwambisi, D., \& Tembo-Nhlema, D. (2020, October 02). volution of national climate adaptation agendas in Malawi, Tanzania and Zambia: the role of national leadership and international donors. Regional Environmental Change, 20(118). doi:https://doi.org/10.1007/s10113-020-01693-8

Pimentel, D., McNair, S., Janecka, J., Wightman, J., Simmonds, C., O'Connell, C., . . Tsomondo, T. (2001, March). Economic and environmental threats of alien plant, animal, and microbe invasions. Agriculture, Ecosystems \& Environment, 84(1), 1-20. doi:https://doi.org/10.1016/S0167-8809(00)00178-X

Pyšek, P., Hulme, P. E., Simberloff, D., Bacher, S., Blackburn, T. M., Carlton, J. T., . . Richardson, D. M. (2020, December). Scientists' warning on invasive alien species. Biological Reviews, 95(6), 1511-1534. doi:https://doi.org/10.1111/brv.12627

Shula, R. K. (2018). Supporting Zambia to Integrate the Agriculture Sector into the National Adaptation Plan (NAP-Ag) Project. Katowice. Retrieved from https://unfccc.int/sites/default/files/resource/Zambia\%20NAP-Agriculture-\%20COP\%2024.pdf

Soanes, M., Bahadur, A. V., Shakya, C., Smith, B., Patel, S., Rumbaitis Del Rio, C., . . Mann, T. (2021). Principles for locally led adaptation. London: IIED. Retrieved from https://pubs.iied.org/10211iied

Tebboth, M. G., Few, R., Assen, M., \& Degefu, M. A. (2020, April). Valuing local perspectives on invasive species management: Moving beyond the ecosystem service-disservice dichotomy. Ecosystem Services, 42. doi:https://doi.org/10.1016/j.ecoser.2020.101068

UN. (2015). The Global Goals. Retrieved March 31, 2021, from Goal 15: Life on Land: http://www.globalgoals.org/15-life-on-land

UN. (2021, March). System of Environmental Economic Accounting - Ecosystem Accounting. Retrieved March 31, 2021, from System of Environmental Economic Accounting: https://seea.un.org/ecosystem-accounting

UNDP. (2018, May 23). Zambia is stepping up efforts for a climate-resilient future. Retrieved March 18, 2021, from https://www.adaptation-undp.org/zambia-stepping-efforts-climate-resilient-future

UNFCCC. (2010). Cancun Adaptation Framework. Retrieved from https://unfccc.int/tools/cancun/adaptation/index.html

UNFCCC. (2011). Decision 1/CP.16 The Cancun Agreements: Outcome of the work of the Ad Hoc Working Group on Long-term Cooperative Action under the Convention. Cancun: UNFCCC. Retrieved from https://unfccc.int/resource/docs/2010/cop16/eng/07a01.pdf 
UNFCCC. (2020). COP26 Campaigns. Retrieved March 19, 2021, from COP26: https://ukcop26.org/ukpresidency/campaigns/

UNFCCC. (n.d.). NAPs from Developing Countries. Retrieved 02 20, 2021, from NAP Central: https://www4.unfccc.int/sites/NAPC/Pages/national-adaptation-plans.aspx

UNFCCC. (n.d.). National Adaptation Projects. Retrieved March 18, 2021, from UNFCCC NAP Central: https://www4.unfccc.int/sites/NAPC/Pages/NationalProjects.aspx

USAID. (2016). Climate Change Risk Profile: Zambia. Washington, D.C.: United States Government. Retrieved from https://www.climatelinks.org/sites/default/files/asset/document/2016\%20CRM\%20Fact\%20Sheet $\% 20-\% 20 Z a m b i a . p d f$

USAID. (n.d.). Regional \& Country Risk Profiles and GHG Emissions Fact Sheets. Retrieved March 19, 2021, from Climate Links: https://www.climatelinks.org/climate-risk-management/regionalcountry-risk-profiles

Williams, F., \& Constantine, K. (2019). An invasive species system assessment in Kenya. Nairobi: CABI. Retrieved from https://www.cabi.org/cabi-publications/680773/

\section{Acknowledgements}

Thank you to the CABI staff who reviewed this paper and supported its development - Roger Day, Noah Phiri, Kate Constantine, Lakpo Agboyi, Ivan Rwomushana, an Julien Godwin.

\section{How to cite this paper}

Casey, J (2021) Policy coherence for national climate change adaptation and invasive species management in four countries. Wallingford: CABI

\section{(bi) CABI}

This study was produced as part of the Action on Invasives programme, implemented by CABI. 